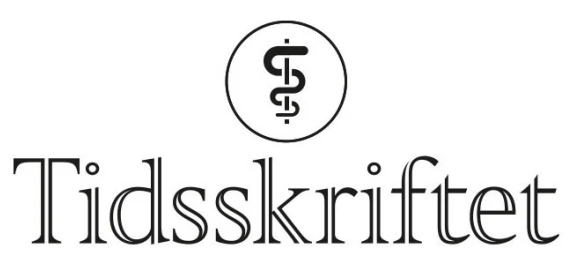

DEN NORSKE LEGEFORENING

\title{
Global handling nå!
}

\section{MINILEDER}

\section{ARE BREAN}

Sjefredaktør

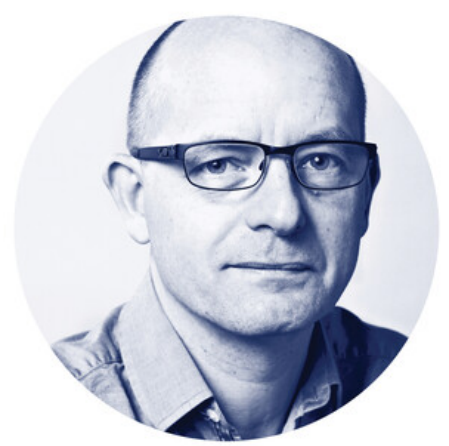

I denne utgaven av Tidsskriftet publiserer vi en lederartikkel på engelsk om behovet for øyeblikkelig handling i møte med vår tids største helsetrussel: klimakrisen. Artikkelen er skrevet av 17 redaktører for ulike medisinske tidsskrifter og signert av godt over 100 redaktører i medisin- og helsetidsskrifter over hele verden. Den publiseres samtidig i alle disse tidsskriftene.

Initiativet kommer fra The UK Health Alliance on Climate Change, som er en sammenslutning av 21 britiske helseorganisasjoner, blant dem The British Medical Journal og The Lancet. Publiseringstidspunktet er ikke tilfeldig: 14. september 2021 åpnes FNs generalforsamling, og senere i høst avholdes FNs 26. klimakonferanse. Som redaktører for helsetidsskrifter står vi sammen om å oppfordre verdens ledere generelt, og de rike landene spesielt, til umiddelbar innsats for å minske den globale temperaturstigningen og beskytte folkehelsen mot de ødeleggende konsekvensene. 2021 bør bli året da menneskeheten tar sin egen fremtid på alvor.

Publisert: 6. september 2021. Tidsskr Nor Legeforen. DOI: 10.4045/tidsskr.21.12.01

(C) Tidsskrift for Den norske legeforening 2023. Lastet ned fra tidsskriftet.no 26. april 2023. 